\title{
A Maldição e a Redenção de Cã: Escravidão Negra e Racismo no Brasil
}

\author{
Ham's Curse and Redemption: \\ Black Slavery and Racism in Brazil
}

Luís Corrêa Lima

\section{Resumo}

A campanha mundial "Vidas negras importam" (Black lives matter) contagia a sociedade no combate ao racismo e à violência contra a população negra. Constitui também uma oportunidade para revisitar o passado escravista da sociedade brasileira e a difusão de teorias raciais que afirmavam a inferioridade de todos os não brancos em relação aos brancos. Neste passado, a escravidão também era parte da cristandade colonial ibérica e católica em expansão. A Bíblia e a teologia tiveram um papel muito importante na cultura escravocrata, especialmente na legitimação da escravidão negra através do relato da Maldição de Cã (Gn 9,18-29). Este relato é depois ressignificado no quadro "A Redenção de Cam" (1895), do pintor Modesto Brocos, principal expressão iconográfica das teorias raciais que visavam o branqueamento progressivo da população brasileira através da mestiçagem. A sociedade se transformou, bem como o cristianismo católico onde se operou uma evolução da doutrina. As marcas da escravidão e da discriminação racial ainda persistem, de certo modo, mas há novas forças agindo em favor da cidadania plena dos negros, inclusive nas confissões cristãs.

Palavras-chave: Escravidão negra. Maldição. Redenção de Cã. Racismo.

\section{Abstract}

The worldwide campaign "Black Lives Matter" seduces society in the fight against racism and violence against the black population. It is also an 
opportunity to revisit the slave past of Brazilian society and a spread of racial theories that affirmed the inferiority of all non-whites in relation to whites. In the past, slavery was also part of the expanding Iberian and Catholic colonial Christianity. The Bible and theology played a very important role in slave culture, especially in legitimizing black slavery through the account of the Curse of Ham (Gen. 9:18-29). This account is later reframed in the painting " $A$ Redenção de Cam" (1895), by the painter Modesto Brocos, an iconographic expression of racial theories that aimed at the progressive whitening of the Brazilian population through miscegenation. Society changed, as did Catholic Christianity, where an evolution of doctrine took place. The marks of slavery and racial discrimination still persist, in a way, but there are new forces at work in favor of full black citizenship, including in Christian confessions.

Keywords: Black slavery. Curse. Ham's Redemption. Racism.

\section{Introdução}

A morte do negro norte-americano George Floyd desencadeou uma onda mundial de protestos contra o racismo, que se concretiza especialmente na violência policial contra a população negra. O lema "Vidas negras importam" (Black lives matter) contagiou multidões. Inúmeros depoimentos de discriminação racial vieram à tona, revelando um cotidiano de opressão em comportamentos sociais e modos de proceder naturalizados. Pode-se dizer que isto é a ponta do iceberg de uma realidade fortemente impregnada na sociedade e na história, inclusive no Brasil.

A ciência histórica pode contribuir para um conhecimento mais amplo desta realidade, que envolve o passado da sociedade brasileira, do cristianismo e da Igreja. Por isso, uma lei federal tornou obrigatório o ensino sobre história e cultura afro-brasileira no ensino fundamental e médio. O conteúdo abrange história da África e dos africanos, a luta dos negros no Brasil, a cultura negra brasileira e o negro na formação da sociedade nacional, resgatando a sua contribuição nas áreas social, econômica e política da história brasileira. Esta história e cultura afro-brasileira deve ser ministrada no âmbito de todo o currículo escolar, em especial nas áreas de educação artística, literatura e história. ${ }^{1}$ E outra lei estabelece

${ }^{1}$ BRASIL, Lei no 10.639 , de 9 de janeiro de 2003. 
o Dia Nacional de Zumbi e da Consciência Negra, a ser comemorado anualmente em 20 de novembro, data do falecimento do líder negro Zumbi dos Palmares. ${ }^{2}$ Estas leis são instrumentos importantes de políticas públicas para fortalecer a autoestima da população negra e apoiar sua luta por mais efetiva cidadania.

\section{A cristandade e a escravidão negra}

A escravidão negra no Brasil e, em certa medida, o racismo interagiram com o cristianismo e sua teologia. A expansão ibérica que dá origem a este país e a tantos outros é uma ampla dilatação de impérios católicos, onde a religião sustentava uma visão de mundo e um conjunto de valores sociais amplamente compartilhado. Não se pode deixar de tratar da escravidão ao se falar da população negra no Brasil, visto que a grande maioria da população vinda da África para a América era constituída de pessoas escravizadas.

Este jugo sempre esteve presente na história da humanidade em diferentes culturas, da Antiguidade greco-romana à América pré-colombiana. $\mathrm{Na}$ Antiguidade, havia servos legais, que eram os prisioneiros em "guerra justa" e os que vendiam a si mesmos ou os próprios filhos; bem como os servos "naturais", conforme a expressão de Aristóteles, que eram homens e mulheres por natureza destinados a servir a outros homens e mulheres livres. ${ }^{3}$ O termo escravo, propriamente, surge na Europa medieval no século X, quando se constituiu o Sacro Império Romano-germânico. Referia-se às tribos eslavas refratárias à evangelização, que eram reduzidas à servidão. Houve um próspero comércio de servos eslavos destinados aos reinos muçulmanos, o que levou à introdução do termo escravo em latim e em árabe. ${ }^{4}$ Este termo existe nas línguas neolatinas e mesmo em inglês, onde slave significa tanto escravo como eslavo.

No século XV, com a tomada de Constantinopla pelos turcos (1453), os mercados escravistas do Mar Negro fecharam suas portas ao Ocidente. Ao mesmo tempo, os navegantes portugueses criaram enclaves costeiros na África negra, descobrindo um vasto comércio de escravos entre tribos africanas, existente desde tempos muito antigos. Até meados do século XVII, a maior parte dos escravizados na África negra se destinava ao Marrocos,

\footnotetext{
${ }^{2}$ BRASIL, Lei ${ }^{\circ} 12.519$, de 10 de novembro de 2011.

${ }^{3}$ ARISTÓTELES, Política, cap. III e IV.

${ }^{4}$ VERLINDER, C., L'esclavage dans l'Europe médiévale, t. II, p. 119; ANDRÉS-GALLEGO, J., La argumentación religiosa de la esclavitud en América, p. 6 e 13.
} 
Trípoli, Egito e Sul da Arábia. Os portugueses se conectaram a este mercado e o estruturaram. O escravo era moeda de troca oferecida pelos africanos aos produtos portugueses, sobretudo armas de fogo. Com o desenvolvimento colonial das Américas, comerciantes europeus de outras nações também aportaram na costa africana com navios negreiros, e o comércio transatlântico superou o norte-africano e o oriental. ${ }^{5} \mathrm{O}$ maior receptor de escravos nas Américas foi o Brasil, onde se calcula que, até 1850, chegaram pelo menos 4,8 milhões de pessoas ${ }^{6}$.

Como esta prática se compatibilizava com a religião dos colonizadores europeus? Na religião cristã, acredita-se que todo ser humano foi criado à imagem e semelhança de Deus $(\mathrm{Gn} 1,27)$ e foi redimido por Cristo, que entregou sua vida em expiação pelos pecados de toda a humanidade (1Jo 2,1-2). Nisto todos os seres humanos são iguais. Mas na tradição judaicocristã também se conhece a escravidão, então chamada servidão. As traduções modernas da Bíblia usam tanto "servo" como "escravo". No Decálogo transmitido por Moisés ao povo hebreu pode-se constatar a sua existência: "Não cobiçarás a casa do teu próximo; não cobiçarás a mulher do teu próximo, nem seu escravo, nem sua escrava, nem seu boi, nem seu jumento, nem nada do que lhe pertence" (Ex 20,17). Igualdade e subordinação coexistem.

A própria linguagem religiosa utiliza comparações e metáforas tiradas de uma vida social marcada pela escravidão, conforme este exemplo: "Como os olhos dos escravos estão fitos na mão dos seus senhores, e os olhos da escrava, na mão de sua senhora, assim os nossos olhos estão fitos no Senhor, nosso Deus, até que tenha piedade de nós" (S1 123,2). A relação entre senhor e escravo é de certo modo referência da relação entre Deus e seu povo eleito. Ao chamado do Senhor, o profeta Samuel responde: "Fala, que teu servo escuta" $(1 \mathrm{Sm} 3,10)$; da mesma forma que Maria de Nazaré, convocada pelo anjo do Senhor a ser mãe de Jesus: "Eis aqui a serva do Senhor! Faça-se em mim segundo a tua palavra" (Lc 1,38). Jesus Cristo é o servo exemplar de Deus Pai que:

Existindo em forma divina, não se apegou à sua condição, mas se despojou, assumiu a forma de escravo e se assemelhou ao ser humano. E se humilhou ainda mais, fazendo-se obediente até a morte de cruz. Por isso, Deus Pai o exaltou acima de tudo e lhe deu o nome que está acima de todo nome (Fl 2,6-9).

\footnotetext{
${ }^{5}$ ANDRÉS-GALLEGO, J., La argumentación religiosa de la esclavitud en América, p. 14-15.

${ }^{6}$ KLEIN, H., Demografia da escravidão, p. 185.
} 
Ao se tornar cristão, o escravo é considerado um "liberto do Senhor"; e quem era livre se torna "um escravo de Cristo" (1Cor 7,22). Há uma sacralização da ordem social, algo comum na história das religiões. De certo modo, a Bíblia reflete a situação do mundo antigo, em que a escravidão aparece como um fenômeno natural. ${ }^{7}$ Afirma-se que Deus não faz acepção de pessoas e que todos os fiéis são um em Cristo, de modo que "já não há judeu nem grego, nem escravo nem livre, nem homem nem mulher" (G1 3,28). Mas esta igualdade convive com a subordinação da mulher ao marido, dos filhos aos pais e dos escravos aos senhores. Os escravos devem obedecer a seus senhores como a Cristo, e os senhores devem tratá-los sem ameaças, sabendo que o Senhor de todos está nos céus e recompensa a cada um pelo bem que faz (Ef 5,21-6,9). Há um caso emblemático de um escravo fugido, Onésimo, convertido pelo apóstolo Paulo na prisão. Ele deve retornar ao seu senhor, Filêmon. Como o senhor e o escravo são cristãos, Paulo exorta Filêmon a receber Onésimo como um irmão, e mais, como se Filêmon recebesse o próprio Paulo (Fm 10-18). As leis vigentes sobre a escravidão são obedecidas, mas procura-se humanizar a relação entre senhor e escravo.

$\mathrm{Na}$ teologia cristã, de um modo geral, mantem-se esta compreensão até o início do século XIX. Na Idade Média, Tomás de Aquino deparou-se com a questão de cristãos terem escravos infiéis, judeus, sarracenos ou pagãos. Ele diz que é preferível um cristão ter um escravo infiel do que um infiel ter um escravo cristão, pois há mais chance do escravo se tornar cristão do que na situação inversa, em que há mais risco para a fé. E se acaso um senhor cristão estiver sendo influenciado pela religião do escravo infiel, deve se livrar deste. ${ }^{8}$ Não se questiona a escravidão, mas apenas o risco para a fé.

$\mathrm{Na}$ época da colonização do Brasil, a escravidão foi ampla mas não isenta de controvérsia. Teólogos do século XVI defendiam que a escravidão era em princípio justa. Supostamente fazia parte da lei natural que os povos vencedores de uma guerra justa reduzam à escravidão os soldados do exército vencido. A exceção a esta lei é a proibição da Santa Sé que povos cristãos façam escravos de outros povos cristãos. Outros dois motivos considerados justos são a venda dos filhos pelos pais, em caso de extrema necessidade, e a pena de escravidão por homicídio e roubo, que existia na legislação de certos povos. ${ }^{9}$ Com relação aos indígenas e outros povos nativos, não era lícito

\footnotetext{
${ }^{7}$ LIPINSKI, É., Escravo, p. 458-459.

${ }^{8}$ ST II, II, q. 10, art. 9.

${ }^{9}$ MERCADO, T., Suma de tratos y contratos, libro II, cap. XXI.
} 
escravizá-los sem motivo, como expressa o Breve Pastorale officium, do papa Paulo III, em 1537:

Nós, portanto, atentos ao que os próprios índios, embora estando fora do seio da Igreja, não sejam privados nem ameaçados de privação da sua liberdade ou do domínio de sua propriedade, pois são homens e por isto capazes de fé e salvação, e não devem ser destruídos pela escravidão, mas antes, por pregação e exemplos, convidados para a vida. ${ }^{10}$

O missionário jesuíta Manuel da Nóbrega constatou a ampla escravização injusta de indígenas e a denunciou severamente às autoridades. Pede ao rei de Portugal providências para que todos os escravos "salteados", isto é, escravizados por meio de sequestro, retornem à sua terra; que por parte da justiça "se saiba e se tire a limpo" pois disto depende a paz e a conversão do gentio. Que "ElRei" enviasse inquisidores e comissários para libertar os escravos, ao menos os que são salteados, e fazê-los viver entre cristãos. Mas nem toda escravização era considerada injusta por este missionário, como no caso de guerra aos portugueses, de certas situações de miséria em que os pais vendiam os filhos, ou da vinda de "escravos de Guiné”, nome genérico dado aos africanos, para trabalharem no sustento dos alunos dos colégios da Companhia de Jesus. Nóbrega defendia a sujeição do gentio, isto é, o domínio da Coroa portuguesa sobre os indígenas do Brasil. Entre tantas vantagens, segundo ele, é que cessariam muitas maneiras de se "haver escravos mal havidos", de modo injusto, porque os homens teriam escravos legítimos, adquiridos em guerra justa, tendo serviço e vassalagem dos índios. Sempre segundo Nóbrega: a terra se povoaria; Nosso Senhor ganharia muitas almas; e Sua Alteza enriqueceria ainda mais, porque haveria muitas criações e engenhos, uma vez que haveria escassez de ouro e prata. ${ }^{11}$

Sobre vinda de escravos africanos para o trabalho nos colégios, foi pedida a autorização ao superior geral da ordem, padre Diogo Laínez, residente em Roma. Ele respondeu que não há inconveniência em ter escravos para cuidar do gado, trabalhar na pesca ou no que for necessário para a manutenção das casas, desde que sejam legitimamente adquiridos. E acrescenta: "digo isto porque ouvi que alguns são feitos escravos injustamente". ${ }^{12}$

\footnotetext{
${ }^{10}$ Pastorale Officium, 1495.

${ }^{11}$ NÓBREGA, M., Manuel da Nóbrega, p. 66, 96, 337-362, 237, 252, 247.

${ }^{12}$ Carta do Pe. Diego Laínez ao Pe. Manuel da Nóbrega, 16 dez. 1562. LEITE, S., Monumenta Brasiliae, 68, 5 .
} 
A denúncia de escravização injusta na África circulava amplamente. Um teólogo dominicano espanhol, Tomás de Mercado, publicou um manual de negócios aos mercadores de Sevilha, que era então o maior porto comercial do mundo. Entre outras coisas, ele trata do comércio de escravos em Cabo Verde, arquipélago da África ocidental, então colônia de Portugal. Neste lugar, os proprietários de escravos são obrigados a ter uma declaração registrada por um escrivão, dizendo que o escravo era de buena lei y guerra. Mas ele relata que a maioria esmagadora dos escravos era de pacíficos habitantes do interior da África. Eles foram cruelmente sequestrados e levados cativos para a costa, "enganados, violentados, forçados e furtados". ${ }^{13}$ Não havia nenhum motivo justo, só a pura ambição. Os portugueses e castelhanos chegavam na costa da África, oferecendo grandes quantias por um escravo, e os africanos saiam ávidos pelo interior do Continente, caçando gente para escravizar como se fossem animais. Ao título de guerra justa se misturavam "muitas ou quase todas injustas". ${ }^{14}$

É preciso dizer, porém, que Tomás de Mercado não era um opositor coerente ao comércio de escravos mal havidos. Ao tratar do tabelamento de preços, afirma que se este mal feito, trará prejuízo a toda gente e à Coroa. E dá como exemplo o caso do tabelamento dos escravos. Para ele, ao fixar o preço do escravo de Cabo Verde em 60 Ducados; em São Domingos, em 100; no México, em 120; e no Peru, em 150, o rei não atrairia os mercadores, pois, eles não iram bancar os custos e enfrentar os riscos por essa quantia. Tomás Mercado afirma que, por isso, estariam faltando escravos nas Américas e nas minas, pois quando o preço em Cabo Verde era de 50 a 55 Ducados, havia muito mais comércio. Conclui afirmando que se os preços voltassem ao que eram antes, haveria mais mercadores em Cabo Verde, mais escravos nas Américas, mais produção nas minas e os mais impostos para sua majestade..$^{15}$ Este teólogo prescinde totalmente do que ele ensina em outra parte da obra, analisando a escravidão do ponto de vista estritamente econômico.

Durante o século XVI, a maioria dos teólogos que trataram deste assunto concluiu ser ilícito manter como escravo alguém cuja legitimidade da escravidão não estivesse provada. Nos últimos anos deste século, porém, a maioria dos teólogos jesuítas, desde Luís de Molina, afirma que isto era exigível apenas do primeiro comprador de escravos africanos. Do segundo

\footnotetext{
${ }^{13}$ MERCADO, T., Suma de tratos y contratos, libro II, cap. XXI.

${ }^{14}$ MERCADO, T., Suma de tratos y contratos, libro II, cap. XXI.

${ }^{15}$ MERCADO, T., Suma de tratos y contratos, libro II, cap. VII.
} 
e do terceiro comprador (e dos demais), que agiam de boa-fé e não tinham meios de averiguar a origem, isto não se podia exigir. ${ }^{16}$

Esta controvérsia chegou ao Brasil. O jesuíta Miguel Garcia (15501614), professor de teologia no colégio jesuíta de Salvador (BA), propunha recusar a absolvição aos que confessavam guardar escravos em casa, vivendo às custas do seu trabalho. A proposta gerou escândalo, pois o próprio colégio se mantinha pelo trabalho escravo africano. Veio um visitador da ordem averiguar a questão. Ele consultou as autoridades responsáveis por assuntos eclesiásticos em Portugal, que era a Mesa de Consciência e Ordens, e também consultou os principais moralistas e juristas, entre os quais Luís de Molina. Todos foram unânimes em dizer que podia haver "cativeiro justo". ${ }^{17}$ Então o visitador deu um parecer contrário a Garcia. Este embarcou para a Europa em 1583, mas pouco antes escreveu uma carta ao superior geral dos jesuítas, na qual desabafou:

\begin{abstract}
A multidão de escravos que tem a Companhia nesta Província, particularmente neste colégio, é coisa que de maneira nenhuma posso tragar, maxime (sic) por não poder entrar no entendimento serem licitamente havidos [...]. Alguma vez me passou por pensamento que mais seguramente serviria a Deus e me salvaria in saeculo (no mundo) que em Província, onde vejo as coisas que vejo. ${ }^{18}$
\end{abstract}

Nota-se que esta indignação de alguns, mesmo sendo justa, não questionava propriamente a legitimidade da escravidão, o sistema como um todo, mas apenas certa maneira como era realizada. E, ainda assim, não se tinha como provar que um escravo era ilicitamente havido e que seu cativeiro era injusto. Outras ordens religiosas também tinham escravos, além de clérigos diocesanos e fiéis leigos.

Em todo este processo, havia também o ideário de expansão da cristandade ibérica, que está na raiz das conquistas territoriais, da colonização e da assimilação de novas populações. Este ideário se configura no imperativo de dilatar a fé e o império, como dizia Luís de Camões, um importante poeta daquela época. ${ }^{19}$ A religião católica tinha um forte impulso ao mesmo tempo

\footnotetext{
${ }^{16}$ MOLINA, L., De iustitia et iure tomi sex, t. I, tract. II, disp. 32-36; ANDRÉS-GALLEGO, J., Los argumentos esclavistas y los argumentos abolicionistas, p. 74.

${ }^{17}$ LEITE, S., História da Companhia de Jesus no Brasil, p. 227-228.

${ }^{18}$ LEITE, S., História da Companhia de Jesus no Brasil, p. 227-228.

${ }^{19}$ CAMÕES, L., Os Lusíadas, Canto I.
} 
universalista e exclusivista. Considerava que a salvação oferecida por Deus se destina a toda a humanidade, mas vem exclusivamente por meio de Jesus Cristo e exige a incorporação na Igreja Católica. Por muitos séculos predominou a máxima "fora da Igreja não há salvação". ${ }^{20}$ Isto foi dito primeiramente por Cipriano de Cartago, no século III, para refutar os donatistas que negavam a salvação dentro da Igreja. Para Cipriano, há salvação na Igreja, sim. Neste caso, fora é que não há. Porém, esta máxima adquiriu um sentido restritivo com Fulgêncio de Ruspe, no século VI, excluindo todos os que estivessem fora da Igreja mesmo sem culpa própria. E assim foi entendido no segundo milênio até o início do século XIX. Na época da colonização do Brasil, a cristandade católica acreditava no que afirmou categoricamente o Concílio Ecumênico de Florença, em 1442:

\begin{abstract}
A Igreja crê firmemente, confessa e anuncia que "nenhum dos que estão fora da Igreja Católica, não só os pagãos", mas também os judeus ou hereges e cismáticos, poderá chegar à vida eterna, mas irão para o fogo eterno "preparado para o diabo e para os seus anjos" [Mt 25,41], se antes da morte não tiverem sido a ela reunidos; ela crê tão importante a unidade do corpo da Igreja, que só para aqueles que nela perseveram os sacramentos da Igreja trazem a salvação e os jejuns, as outras obras de piedade e os exercícios da milícia cristã podem obter o prêmio eterno. Nenhum, por mais esmolas que tenha dado, e mesmo que tenha derramado o sangue pelo nome de Cristo, poderá ser salvo se não permanecer no seio e na unidade da Igreja Católica. ${ }^{21}$
\end{abstract}

Também os escravos vindos da gentilidade eram incorporados à Igreja Católica. Catequese, pregações e sacramentos também se destinam a eles. Os senhores são exortados a cumprirem suas obrigações espirituais para com os escravos, fossem indígenas ou africanos. Para o padre José de Anchieta, contemporâneo de Nóbrega, é preciso considerar que Cristo, sendo Deus, fezse humano; sendo Senhor, fez-se escravo. Os senhores do Brasil não devem ver seus escravos como meros boçais e bestiais que custaram direito, mas ver em cada um deles representada:

A imagem de Cristo Nosso Senhor, que se fez escravo para salvar este escravo e me serviu como escravo trinta e três anos, por me salvar a

\footnotetext{
${ }^{20}$ Extra ecclesiam, nulla salus.

${ }^{21}$ Cantate Domino, 1350.
} 
mim, que era escravo do diabo, para que eu também me faça agora seu escravo, trabalhando por seu serviço, em salvar-me a mim e a alma de meu escravo. ${ }^{22}$

A escravidão, portanto, está naturalizada e é lida em chave espiritual: Deus se faz meu escravo para me oferecer a salvação, para que eu me torne escravo Seu, trabalhando para consumar esta salvação em mim e em meu escravo. Toda a vida de Cristo na terra, do nascimento à morte, é um longo cativeiro. Tornar-se Seu discípulo é ser cativo também, é ser um escravo do bem a caminho do céu. São ecos dos ensinamentos do apóstolo Paulo sobre o Cristo escravo (F1 2,5-11) e o discípulo escravo (1Cor 7,22).

No século XVII, o padre jesuíta Antônio Vieira, renomado pregador luso-brasileiro, dirige-se aos negros, a quem chama de "etíopes". Exorta-os à ação de graças por saírem do mundo pagão, caminho inexorável de perdição eterna, e adentrarem em uma terra cristã onde podem alcançar a salvação.

Falo mais particularmente com os pretos [...] deveis dar infinitas graças a Deus [...] por vos ter tirado de vossas terras, onde vossos pais e vós vivíeis como gentios, e vos ter trazidos a esta, onde, instruídos na fé, vivais como cristãos, e vos salveis. [...] Oh! se a gente preta, tirada das brenhas da sua Etiópia, e passada ao Brasil, conhecera bem quanto deve a Deus e a sua Santíssima Mãe por este que pode parecer desterro, cativeiro e desgraça, e não é senão milagre, e grande milagre? Dizei-me: vossos pais, que nasceram nas trevas da gentilidade, e nela vivem e acabam a vida sem lume da fé nem conhecimento de Deus, aonde vão depois da morte? Todos, como credes e confessais, vão ao inferno, e lá estão ardendo e arderão por toda a eternidade. ${ }^{23}$

Novamente afirma-se de maneira generalizada e categórica que fora da Igreja não há salvação. E, no mesmo sermão, Vieira acrescenta: "não há trabalho nem gênero de vida no mundo mais parecido à Cruz e Paixão de Cristo que o vosso em um destes engenhos". ${ }^{24}$ Por isso, toda a tragédia que podia haver na escravidão negra - incluindo as humilhações de captura, traslado e cativeiro - era vista como algo muito menor comparado à eternidade feliz em lugar da condenação. Não há dúvida de que a incorporação dos gentios africanos à cristandade por meio da escravidão, também serviu para legitimá-la.

${ }^{22}$ ANCHIETA, J., Sermões, p. 48.

${ }^{23}$ VIEIRA, A., Sermão XIV (1633), VI.

${ }^{24}$ VIEIRA, A., Sermão XIV (1633), VII. 
Vieira também se envolveu na questão do Quilombo dos Palmares. Os quilombos eram povoações que abrigavam escravos fugidos, constituindo-se em uma alternativa ao poder colonial. Palmares era parte de uma rede bem organizada de quilombos e se tornou o maior contingente de escravos fugidos na história da América portuguesa. ${ }^{25}$ Segundo Vieira, um missionário jesuíta italiano se ofereceu para dar assistência religiosa ao quilombo. A questão chegou ao rei de Portugal. O próprio Vieira escreveu ao secretário do rei, opondo-se com veemência a tal assistência, porque ainda que os quilombos cessassem os assaltos aos povoados dos portugueses, nunca deixariam de admitir outros escravos fugidos. E, por se tratar de cativos rebelados, estão e perseveram em pecado contínuo. Não podem ser absolvidos no sacramento da penitência e nem receber a graça de Deus, a menos que sejam restituídos aos seus senhores, o que de modo nenhum aceitarão. ${ }^{26}$

Só haveria um meio de remediar a situação, que é o rei de Portugal e todos os senhores daqueles escravos espontaneamente lhe concederem a liberdade. Assim eles viveriam naqueles lugares como outros índios e gentios livres, e os padres seriam seus párocos e os doutrinariam como os demais. "Porém esta mesma liberdade assim considerada seria a total destruição do Brasil, porque conhecendo os demais negros que por este meio tinham conseguido o ficar livres, cada cidade, cada vila, cada lugar, cada engenho, seriam logo outros tantos Palmares", com a fuga generalizada de escravos em direção aos matos. ${ }^{27}$

\section{A maldição e a redenção de Cã}

Diversos textos da Bíblia serviram para compor a cultura escravocrata moderna no Ocidente, que justificava a aquisição e a manutenção de escravos. Mas um destes textos serviu para justificar especificamente a escravidão de africanos. É o relato da maldição de Cã (Gn 9,18-29). Após o dilúvio universal, Noé tornou-se agricultor, plantou uma vinha, tomou vinho, embriagou-se e ficou nu em sua casa. Um de seus filhos, Cã, viu a nudez do pai e contou a seus irmãos, Sem e Jafé. Estes puseram o manto nos ombros e caminharam de costas em direção ao pai. E, sem verem a sua nudez, cobriram-no. Ao despertar, Noé ficou sabendo do que Cã tinha feito e amaldiçoou a descendência deste

${ }^{25}$ NASCIMENTO, R., Palmares, p. 9.

${ }^{26}$ VIEIRA, A., Carta a Roque Monteiro Paim (2 jul. 1691), p. 617-622.

${ }^{27}$ VIEIRA, A., Carta a Roque Monteiro Paim (2 jul. 1691), p. 617-622. 
filho, condenando-a a tornar-se escrava de Sem e Jafé. Cã e sua descendência foram associados ao Egito e, por extensão, à África. Esta suposta razão bíblica foi compartilhada por judeus, muçulmanos e cristãos durante séculos. Por este argumento, chegava-se por outro caminho à mesma posição do filósofo Aristóteles: a existência de escravos naturais. Na maldição de Cã, porém, tratava-se de uma realidade que, segundo a Revelação, era querida por Deus. ${ }^{28}$ A escravidão foi racializada no negro africano.

Aos senhores de escravos do Brasil, foi escrito no início do século XVIII um manual pelo missionário jesuíta italiano Jorge Benci: Economia Cristã dos Senhores no Governo dos Escravos. Trata-se das necessidades materiais e espirituais dos escravos, da disciplina a que se devem submeter e dos serviços que devem realizar. O livro é muito inspirado no éthos bíblico escravocrata, com muitos exemplos e lições tiradas da Sagrada Escritura a respeito dos escravos. Para Benci, a origem da escravidão não estava no plano do Criador. Ele deu a Adão e Eva o domínio apenas sobre as aves de céu e os peixes do mar, para entenderem que seu domínio não passava dos seres brutos e não se estendia aos homens que deles haveriam de nascer. Foi o pecado que abriu as portas por onde entrou o cativeiro no mundo. Rebelando-se o homem contra Deus, rebelaram-se nele e contra ele os seus próprios apetites. Aí está a origem das dissensões e guerras entre povos, nações e reinos. Nas batalhas entre as gentes, achou-se que era mais humano não haver tanto derramamento de sangue. Introduziu-se o direito de perdoar aos vencidos, que se rendiam e se entregavam espontaneamente aos vencedores, não lhes tirando a vida. Os vencedores passavam a ter o domínio e senhorio perpétuo sobre os vencidos, e os vencidos a sujeição perpétua e a obrigação de servir aos vencedores. ${ }^{29}$ Segundo Benci, a primeira origem do cativeiro e da servidão, porém, está no escárnio que fez Cã da desnudez de Noé, seu pai. Em castigo deste abominável atrevimento, o pai amaldiçoou toda a descendência de Cã, que "no sentir de muitos é a mesma geração dos pretos que nos servem". Tal maldição supostamente foi aprovada por Deus e esta descendência foi condenada ao cativeiro e à escravidão. ${ }^{30}$

Em meados do século XVIII, o Iluminismo questiona a escravidão e suas justificações. Na segunda metade deste século, tem início os movimentos abolicionistas, que terão força no Brasil na segunda metade do século XIX,

${ }^{28}$ ANDRÉS-GALLEGO, J., La argumentación religiosa de la esclavitud en América, p. 12-16; BRAUDE, B., Cham et Noé, p. 93-125.

${ }^{29}$ BENCI, J., Economia cristã dos senhores no governo dos escravos, n. 3-4.

${ }^{30}$ BENCI, J., Economia cristã dos senhores no governo dos escravos, n. 31. 
alcançando a abolição da escravatura em 1888. Porém, neste tempo também se desenvolveu a ideia de nação, fortemente ligada à raça. A desigualdade das raças e a inferioridade das raças não brancas eram consideradas verdades científicas. As ideias de francês Joseph Arthur, Conde de Gobineau (18161882), e do anglo-germânico Houston Stewart Chamberlain (1855-1927) tiveram ampla divulgação internacional, inclusive na sociedade brasileira. A abolição não deu acesso a um mundo que aceitasse a igualdade racial.

Em 1895, surge o quadro "A Redenção de Cam”. Esta pintura a óleo foi realizada pelo artista espanhol Modesto Brocos, professor na Escola Nacional de Belas Artes do Rio de Janeiro. A obra, até hoje, faz parte do acervo do Museu Nacional vinculado à Escola. Ela expressa as teorias raciais e a busca do embranquecimento gradual das gerações dentro de um mesmo círculo familiar através da miscigenação.

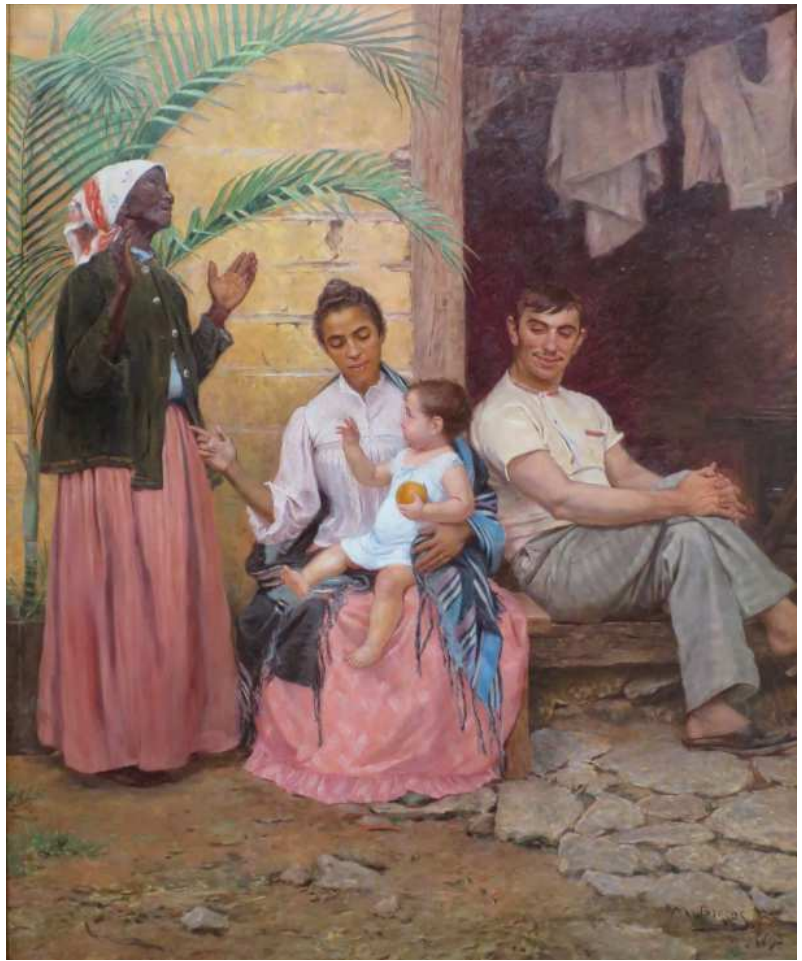

“A redenção de Cam”, de Modesto Brocos (1895) $)^{31}$

\footnotetext{
${ }^{31}$ BROCOS, M., A redenção de Cam. 1895. 1 original de arte, óleo sobre tela, $199 \mathrm{~cm}$ x $166 \mathrm{~cm}$. Coleção Museu Nacional de Belas Artes.
} 
Na imagem, uma mulher negra idosa em pé, diante de sua filha mestiça sentada, exulta ao ver seu neto branco. Ao lado da filha mestiça está sentado um homem branco, pai do menino. A cena tem semelhança com a iconografia religiosa da natividade, em que o bebê no colo da mãe ocupa o centro da imagem, como o menino Jesus no colo da Virgem Maria, ao lado de um homem branco no lugar de São José. O azul do xale usado pela mulher mestiça também alude a Maria, cujo manto tem a mesma cor nas pinturas religiosas. Os pés descalços da avó sugerem que ela havia sido escrava, pois era comum os escravos andarem descalços. Ela pisa o chão de terra, ao passo que a filha mestiça e seu marido estão calçados e pisam o chão de pedra. A cabeça da avó negra está coberta pelo lenço branco, ocultando seu cabelo. A filha mestiça tem a cabeça descoberta, mas seu cabelo crespo está preso. A criança branca e seu pai branco têm o cabelo liso e solto. Este é diferente do cabelo crespo dos negros e mestiços, que vulgarmente era chamado cabelo ruim. Por isso pode estar solto.

A tela recebeu a medalha de ouro no momento em que veio a público pela primeira vez, na Exposição Geral de Belas Artes em 1895. O poeta Olavo Bilac homenageou o quadro na imprensa: "Vede a aurora-criança como sorri e fulgura, no colo da mulata, - aurora filha do dilúculo, neta da noite... Cam está redimido! Está gorada a praga de Noé!" 32 No ideário racial da supremacia branca, Cã redimido é Cã embranquecido. Se permanecer negro, continuará amaldiçoado. Ao manifestar a ideologia do embranquecimento no final do século XIX, a tela é produto e produção de uma longa tradição de pensamento que frutificou no território brasileiro desde os tempos coloniais, representando a expressão iconográfica desse problema de longa duração. Converteu-se em emblema de uma época e de um tipo de pensamento racialista que deixou marcas indeléveis na tradição brasileira. ${ }^{33}$

Em 1911, na Inglaterra, houve o Congresso Universal das Raças, sediado na Universidade de Londres. O encontro teve por objetivo discutir as contribuições das diferentes "raças" para a humanidade, reunindo delegados de todas as partes do mundo. O governo brasileiro escolheu para participar do evento, como seu representante, o médico e antropólogo carioca João Batista de Lacerda, diretor do Museu Nacional. Ele apresentou sua teoria que exaltava o embranquecimento, contrapondo-se a outras teses então em voga segundo

\footnotetext{
${ }^{32}$ BILAC, O., A redempção de Cham, 5 set. 1895, p. 1.

${ }^{33}$ LOTIERZO, T.; SCHWARCZ, L., Raça, gênero e projeto branqueador.
} 
as quais a mestiçagem promovia a degeneração da espécie. Segundo Lacerda, por efeito da evolução e da entrada de imigrantes europeus no Brasil, levaria três gerações ou um século para que o país se tornasse branco.

A comunicação apresentada por Lacerda traz o quadro de Brocos com a legenda: "o negro se torna branco, na terceira geração, por efeito do cruzamento de raças". Ele explica que a questão do mestiço tem uma importância extraordinária no Brasil, dada a sua população amplamente miscigenada. A origem desta miscigenação está nos senhores de escravos que frequentemente tinham escravas como concubinas. As uniões entre brancos e negros se tornaram muito frequentes. Era comum ver senhores de escravos terem na mesa de refeição da família, sem qualquer constrangimento, seus pequenos filhos mulatos. ${ }^{34}$

Para Lacerda, a importação, em larga escala, da raça negra para o Brasil exerceu uma influência nefasta sobre o progresso do país, ao retardar, por muito tempo, o desenvolvimento material da Nação e ao dificultar o aproveitamento de suas imensas riquezas materiais. Ele sustenta que o caráter da população foi marcado pelos defeitos e vícios da raça negra importada. O mestiço, por sua vez, embora inferior ao negro em resistência corporal e força física, rivalizava com o branco em inteligência e em aptidões técnicas e artísticas. No Brasil, os mestiços ajudariam a ação dos brancos em favor do progresso do país. O branqueamento no cruzamento de raças e o desaparecimento do preconceito racial cooperariam para a extinção do mestiço num futuro próximo - antes de um século, provavelmente. O Brasil passaria a ser composto em sua maior parte por indivíduos de raça branca, latinos enquanto que o negro e o índio, sem dúvida desapareceriam. Lacerda concluía asseverando que um futuro brilhante estaria reservado ao Brasil, pois ele tornar-se-ia a principal estação na América do Sul onde a raça latina viria a se revigorar e se rejuvenescer, assim como os Estados Unidos fizeram com a raça anglo-saxônica, na América do Norte. ${ }^{35}$

O representante do governo brasileiro em Londres expressou a visão com a qual o Brasil de então promovia, em nível de política pública, a imigração massiva de italianos, espanhóis, portugueses, alemães, poloneses, lituanos, ucranianos e árabes para embranquecer. Deu a imigrantes europeus oportunidades econômicas que não deu a negros brasileiros recém-saídos do

${ }^{34}$ LACERDA, J., Sur les mêtis au Brésil, p. 10-11.

${ }^{35}$ LACERDA, J., Sur les mêtis au Brésil, p. 29-31. 
cativeiro ou libertos há mais tempo, como amplo acesso à terra e a empregos no mercado formal. O racismo brasileiro é uma herança ancestral, dos tempos da casa grande e da senzala, que depois se reinventou e se sofisticou com teorias raciais inspiradas no darwinismo. Outros tempos vieram, mas a discriminação e a subalternidade da população negra ainda permanecem.

No início do século XX, o papa Pio X afirmou que a sociedade humana, tal como Deus a estabeleceu, é formada por elementos desiguais, como desiguais são os membros do corpo humano. Torná-los todos iguais é impossível, pois disto resultaria a própria destruição da sociedade. ${ }^{36} \mathrm{~A}$ igualdade dos seres humanos consiste apenas no fato de todos terem a sua origem em Deus Criador; serem redimidos por Jesus Cristo e deverem ser julgados por Deus, segundo a regra exata de seus méritos, e por Ele recompensados ou punidos. Disto resulta, conclui o papa, que segundo a ordem estabelecida por Deus "existem na sociedade príncipes e vassalos, patrões e proletários, ricos e pobres, sábios e ignorantes, nobres e plebeus, os quais, todos unidos por um laço comum de amor, se ajudam mutuamente para alcançarem o seu fim último no céu e o seu bem-estar moral e material na terra". ${ }^{37}$

Esta afirmação de Pio X resume a compreensão de ampla maioria do mundo cristão a respeito da igualdade e da desigualdade humana, que vigorou por muitos séculos. Na lista de desigualdades mencionada pelo papa, não consta a racial. Cabe ressaltar que as teorias raciais eram condenadas pela Igreja Católica por suporem que as raças têm origens diferentes, negando a procedência de todos os seres humanos do primeiro casal criado por Deus, Adão e Eva. Mas, mesmo sem adotar teorias raciais, acreditou-se por muitos séculos que na ordem estabelecida pelo Criador devia haver senhores e escravos, "a mesma geração de pretos que nos servem”, conforme a expressão do padre Benci; ou seja, uma escravidão racializada.

$\mathrm{Na}$ sociedade escravista também havia negros libertos, que antes da abolição já haviam se tornado muito mais numerosos do que os escravos. Porém, os libertos não estavam livres da discriminação racial, que existia não só de fato, mas também de direito na instituição religiosa. Um exemplo disso é o acesso ao sacerdócio ministerial. As Constituições Sinodais do Arcebispado de Lisboa, aprovadas em 1640, colocavam como impedimento para promoção às ordens sacras ter "parte de nação hebreia, ou de outra infecta,

\footnotetext{
${ }^{36}$ Motu proprio del sommo pontefice Pio X fin dalla prima, I.

${ }^{37}$ Motu proprio del sommo pontefice Pio X fin dalla prima, II-III.
} 
ou de negro ou de mulato". ${ }^{38}$ Estas Constituições vigoraram no Brasil até a promulgação das Constituições Primeiras do Arcebispado da Bahia, em 1707, que reiteraram este impedimento e o tornaram ainda mais rígido, pois exigiam que fosse verificado já antes de se concederem as ordens menores; isto é, leitor, acólito, exorcista e hostiário. ${ }^{39}$ Havia casos de dispensa eclesiástica do "defeito da cor" e exemplos de descendentes de escravos e de libertos que foram ordenados. Mas a concessão da dispensa para receber as ordens sacras era um privilégio que mantinha a hierarquia notoriamente excludente da sociedade, contribuindo para a manutenção da ordem. ${ }^{40}$

O Brasil foi o último país das Américas a abolir a escravidão. Poucos dias antes da abolição, o papa Leão XIII publicou uma Encíclica saudando o iminente fim do cativeiro neste país. ${ }^{41} \mathrm{O}$ documento pontifício faz uma breve releitura da história da escravidão na perspectiva abolicionista, com uma teologia bem diferente daquela de séculos anteriores. Porém, o combate à discriminação racial ainda estava longe de ser contemplado.

\section{Conclusão}

As teorias da desigualdade das raças e da inferioridade dos não brancos perderam força após a Segunda Guerra Mundial. A derrota do nazismo, que sustentava o mito da raça ariana, os horrores do Holocausto e a proclamação da Declaração Universal dos Direitos Humanos pela ONU, contribuíram para uma nova mentalidade. Passa a vigorar a conviç̧ão de que todos os seres humanos nascem livres e iguais em dignidade e direitos. Os cristãos têm contribuições relevantes nesta nova ordem que combate a discriminação e a segregação racial. Grandes ícones desta causa são o pastor batista norteamericano Martin Luther King Jr. e o bispo anglicano sul-africano Desmond Tutu. Textos bíblicos usados no passado para justificar a escravidão foram reinterpretados. No Brasil, a Campanha da Fraternidade de 1988, ano em se completou cem anos a abolição, teve como tema: "A fraternidade e o negro"; e como lema: "Ouvi o clamor deste povo".

É preciso reconhecer que as marcas da sociedade escravista e do racismo têm uma forte inércia e, de certo modo, ainda permanecem. Mas há novas

\footnotetext{
${ }^{38}$ CUNHA, R., Constituições sinodais do Arcebispado de Lisboa, p. 98.

${ }^{39}$ VIDE, S., Constituições primeiras do Arcebispado da Bahia, p. 224.

${ }^{40}$ ANDERSON, J. Trajetórias de clérigos de cor na América Portuguesa.

${ }^{41}$ In plurimis (5 ago. 1888).
} 
forças atuando em favor da cidadania plena dos negros, que ganham vigor com a campanha "Vidas negras importam". Uma das mensagens mais fortes no Brasil em favor das vidas negras é a Missa dos Quilombos, de 1981, composta pelo bispo dom Pedro Casaldáliga, falecido há pouco tempo, em parceria com o poeta Pedro Tierra e com o cantor Milton Nascimento. O canto de entrada da Missa, A de Ó (Estamos Chegando) ${ }^{42}$ fala de dores e padecimentos destas vidas no passado e no presente, bem como de seus sonhos, suas lutas e sua alegria contagiante:

\section{A de Ó (Estamos Chegando)}

Estamos chegando do fundo da terra, estamos chegando do ventre da noite, da carne do açoite nós somos, viemos lembrar.

Estamos chegando da morte dos mares, estamos chegando dos turvos porões, herdeiros do banzo nós somos, viemos chorar.

Estamos chegando dos pretos rosários, estamos chegando dos nossos terreiros, dos santos malditos nós somos, viemos rezar.

Estamos chegando do chão da oficina, estamos chegando do som e das formas, da arte negada que somos, viemos criar.

Estamos chegando do fundo do medo, estamos chegando das surdas correntes, um longo lamento nós somos, viemos louvar.

\section{A DE Ó}

Estamos chegando dos ricos fogões, estamos chegando dos pobres bordéis, da carne vendida que somos, viemos amar.

Estamos chegando das velhas senzalas, estamos chegando das novas favelas,

${ }^{42}$ MiLTON NASCIMENTO, A de Ó (Estamos Chegando...). M. Nascimento, P. Casaldáliga, P. Tierra. [Compositores]. 
das margens do mundo nós somos,

viemos dançar.

Estamos chegando dos grandes estádios,

estamos chegando da escola de samba,

sambando a revolta chegamos,

viemos gingar.

A DE Ó

Estamos chegando do ventre de Minas, estamos chegando dos tristes mocambos, dos gritos calados nós somos, viemos cobrar.

Estamos chegando da cruz dos engenhos, estamos sangrando a cruz do batismo, marcados a ferro nós fomos, viemos gritar.

Estamos chegando do alto dos morros, estamos chegando da lei da baixada, das covas sem nome chegamos, viemos clamar.

Estamos chegamos do chão dos quilombos, estamos chegando no som dos tambores, dos Novos Palmares nós somos, viemos lutar.

A DE Ó

\section{Referências bibliográficas}

ANCHIETA, J. Sermões: Obras Completas. São Paulo: Loyola, 1987. v.7.

ANDERSON, J. Trajetórias de clérigos de cor na América Portuguesa: catolicismo, hierarquias e mobilidade social. Andes, v. 25, n. 1, jun. 2014. Disponível em: <http://www.scielo.org.ar/scielo.php?script=sci_arttext\&pid $=$ S1668-80902014000100002 $>$. Acesso em: 28 ago. 2020 .

ANDRÉS-GALLEGO, J. La argumentación religiosa de la esclavitud en América. Vitória (Espanha), 2005, p. 1-38. Disponível em: <http:// joseandresgallego.com/docs/SinopsisIglYEsclavitud.pdf $>$. Acesso em: 17 ago. 2020.

ANDRÉS-GALLEGO, J. Los argumentos esclavistas y los argumentos abolicionistas: reconsideración necesaria. Revista del CESLA, n. 7, p. 63-108, 
2005. Disponível em: <https://www.redalyc.org/pdf/2433/243320976004. pdf $>$. Acesso em: 18 ago. 2020.

ARISTÓTELES. Política. Disponível em: <https://social.stoa.usp.br/ fabiomidia/aristoteles.-politica.pdf?view=true>. Acesso em: 17 ago. 2020.

BENCI, J. Economia cristã dos senhores no governo dos escravos (1705). São Paulo: Grijalbo, 1977.

BILAC, O. [pseudônimo ass. Fantasio]. A redempção de Cham. Gazeta de notícias, 5 set. 1895. Fantasio na Exposição II, p. 1.

BRASIL. Lei no 10.639, de 9 de janeiro de 2003. Disponível em: <https://www. planalto.gov.br/ccivil_03/leis/2003/110.639.htm>. Acesso em: 14 ago. 2020.

BRASIL. Lei $\mathrm{n}^{\circ}$ 12.519, de 10 de novembro 2011. Disponível em: <https:// www.planalto.gov.br/ccivil_03/_ato2011-2014/2011/lei/112519.htm>. Acesso em: 14 ago. 2020.

BRAUDE, B. Cham et Noé: race, esclavage et exégèse entre islam, judaïsme et christianisme. Annales. Histoire, Sciences Sociales, v. 57, n. 1, p. 93-125, jan./fev. 2002. Disponível em: <https://www.persee.fr/doc/ ahess_0395-2649_2002_num_57_1_280030>. Acesso em: 20 ago. 2020.

BROCOS, M. A redenção de Cam. 1895. 1 original de arte, óleo sobre tela, 199 cm x 166 cm. Coleção Museu Nacional de Belas Artes. Disponível em: $<$ https://pt.wikipedia.org/wiki/A_Reden\%C3\%A7\%C3\%A3o_de_Cam $>$. Acesso em: 14 ago. 2020.

CAMÕES, L. Os Lusíadas (1572). Belém: Unama. Disponível em: <http:// www.dominiopublico.gov.br/download/texto/ua000178.pdf $>$. Acesso em: 19 ago. 2020 .

CONCÍLIO DE FLORÊNÇA. Bula Cantate Domino sobre a união com os coptas e os etíopes, 4 fev. 1442. In: DENZIGER, H.; HÜNERMANN, P. Compêndio dos símbolos, definições e declarações de fé e moral. São Paulo: Paulinas/Loyola, 2007. p. 366-373.

LIPINSKI, É. Escravo. In: CENTRO INFORMÁTICA E BÍBLIA - ABADIA DE MAREDSOUS (Org.). Dicionário enciclopédico da Bíblia. São Paulo: Loyola / Paulinas / Paulus; Santo André, SP: Academia Cristã, 2013. p. 458-459. CUNHA, R. Constituições sinodais do Arcebispado de Lisboa. Lisboa: Oficina de Paulo Craesbeek, 1656. 
LACERDA, J. Sur les mêtis au Brésil. Rio de Janeiro: Museu Nacional, 1911.

LEITE, S. História da Companhia de Jesus no Brasil. Lisboa: Portugália; Rio de Janeiro: Civilização Brasileira, 1938. t. II.

LEITE, S. Monumenta brasiliae (1558-1563). Roma, 1958. v. 3.

MARROU, H.-I. Teologia da história: o sentido da caminhada da humanidade através da temporalidade. Petrópolis, RJ: Vozes, 1989.

MILTON NASCIMENTO. A de Ó (Estamos Chegando...). M. Nascimento, P. Casaldáliga, P. Tierra. [Compositores]. In: MILTON NASCIMENTO. Missa dos Quilombos. [S.1.]: Universal Music Ltda., 1982. 1 LP (ca. 52 min.). Lado A. Faixa 2 (3 min. 32 s.). Disponível em: <https://www.youtube.com/ watch? $\mathrm{v}=\mathrm{x} 20 \mathrm{xgSydK} 4 \mathrm{M}>$. Acesso em: 30 ago. 2020.

MERCADO, T. Suma de tratos y contratos (1571). Disponível em: $<$ https:// www.biblioteca.org.ar/libros/132175.pdf>. Acesso em: 18 ago. 2020.

MOLINA, L. De iustitia et iure tomi sex. Maguncia / Amberes: Ioannem Keerbergium, 1615. t. I.

NASCIMENTO, R. Palmares: os escravos contra o poder colonial. São Paulo: Terceiro Nome, 2014.

NÓBREGA, M. Manuel da Nóbrega: obra completa. Edição comemorativa - $5^{\circ}$ centenário de nascimento (1517-2017). Rio de Janeiro: Ed. PUC-Rio; São Paulo: Loyola, 2017.

PAULO III, PP. Breve Pastorale Officium ao arcebispo de Toledo, 29 mai. 1537. In: DENZIGER, H.; HÜNERMANN, P. Compêndio dos símbolos, definições e declarações de fé e moral. São Paulo: Paulinas/Loyola, 2007. p. 393.

PIO X, PP. Motu proprio del sommo pontefice Pio X fin dalla prima. Roma, 18 dez. 1903. Disponível em: <http://www.vatican.va/content/pius-X/it/motu_ proprio/documents/hf_p-x_motu-proprio_19031218_fin-dalla-prima.html $>$. Acesso em: 26 ago. 2020.

KLEIN, H. Demografia da escravidão. In: SCHWARCZ, L.; GOMES, F (Org.). Dicionário da escravidão e liberdade: 50 textos críticos. São Paulo: Companhia da Letras, 2018. p. 185.

TOMÁS de Aquino. Suma Teológica: $2^{\mathrm{a}}$ parte da $2^{\mathrm{a}}$ parte - questões 1-189. Caxias do Sul: Est-Sulina-UCS, 1980. v. V-VII. 
VERLINDER, C. L'esclavage dans l'Europe médiévale. Gante: Rijksuniversiteit te Gent, 1977. t. II.

VIDE, S. Constituições primeiras do Arcebispado da Bahia. São Paulo: Edusp, 2010.

VIEIRA, A. Sermões. Erechim (RS): Edelbra, 1998. v. V. Disponível em: $<$ http://www.dominiopublico.gov.br/download/texto/fs000032pdf.pdf $>$. Acesso em: 17 ago. 2020.

VIEIRA, A. Carta a Roque Monteiro Paim (2 jul. 1691). In: VIEIRA, A. Cartas do Padre António Vieira. Coimbra: Imprensa da Universidade, 1928. p. 617-622. v. 3. Disponível em: <https://www.yumpu.com/pt/document/ view/12911874/carta-de-antonio-vieira-a-roque-monteiro-paim-2-de-julhode-1691->. Acesso em: 20 ago. 2020.

Luís Corrêa Lima

Doutor em História pela Universidade de Brasília Docente do Programa de Pós-Graduação em Teologia da Pontifícia Universidade Católica do Rio de Janeiro Rio de Janeiro / RJ - Brasil E-mail: lclima@puc-rio.br

Recebido em: 30/08/2020

Aprovado em: 21/11/2020 